Marquette University

e-Publications@Marquette

Social and Cultural Sciences Faculty Research and

Publications

Social and Cultural Sciences, Department of

6-1-2018

\title{
Ethnographic Advocacy Against the Death Penalty
}

Jesse Cheng

Marquette University, jesse.cheng@marquette.edu

Accepted version. Anthropology and Humanism, Vol. 43, No. 1 (June 2018): 21-38. DOI. (C) 2018

American Anthropology Association. Used with permission. 


\section{Marquette University}

\section{e-Publications@Marquette}

\section{Sociology Faculty Research and Publications/College of Arts and Sciences}

This paper is NOT THE PUBLISHED VERSION; but the author's final, peer-reviewed manuscript. The published version may be accessed by following the link in the citation below.

Anthropology and Humanism, Vol. 43, No. 1 (June 2018): 21-38. DOI. This article is (C) American Anthropology Association and permission has been granted for this version to appear in ePublications@Marquette. American Anthropology Association does not grant permission for this article to be further copied/distributed or hosted elsewhere without the express permission from American Anthropology Association.

\section{Ethnographic Advocacy Against the Death Penalty}

Jesse Cheng: Social and Cultural Sciences, 347 Lalumiere Language Hall Marquette University, Milwaukee, WI

\section{SUMMARY}

This article develops the concept of "ethnographic advocacy" to make sense of the humanizing, open-ended knowledge practices involved in the defense of criminal defendants charged with capital murder. Drawing from anthropological fieldwork with well-respected figures in the American capital defense bar, as well as my own professional experience as an investigator specializing in death penalty sentencing mitigation, I argue that effective advocacy for life occurs through qualitative knowledge practices that share notable methodological affinities with contemporary anthropological ethnography. The article concludes with a preliminary exploration of what the concept of ethnographic advocacy might reveal about academic anthropology's own advocative engagements. 


\section{Introduction}

Those who defend individuals charged with capital murder in the United States perceive themselves to practice a distinct brand of legal advocacy. They view their opponent, the state apparatus, to wield considerable advantages in funding, technology, expertise, political networks, manpower, procedurally embedded bias, and, oftentimes, public support, all channeled with directed intention on the specific goal of negating their client's life. This singularity of purpose becomes sharpened through theoretical processes of reduction: the defendant is equated with the evil of an aggravated murder, stripped of the profound subtleties and contradictions that inhere in his humanity so that society can find justification in stripping itself of his very being. Advocates who have never experienced a death penalty case find the tried-and-true rubrics of standard criminal defense practice to be grossly inadequate in this field of death. To avoid the ultimate punishment, capital defenders must somehow subvert the state's objectifying designs-its attempts to impose analytical rigor mortis on curious, lively, and life-minded inquiries into the complex currents that weave through and coalesce in the defendant's personhood. The threat is one of thought paralysis. In the face of such fixed purpose, perpetual movement in the production of knowledge assumes vital significance, literally, in maintaining the client's continued existence.

Such is the gestalt of the capital defense advocate's mindset, as I gleaned from nine months of anthropological fieldwork across the country with some of the most experienced and highly regarded practitioners in the nation's death penalty defense community. These impressions, subsequently refined during eight years as a fulltime sentencing investigator for the defense, revolve around the sophisticated advocacy processes known in the work as death penalty "mitigation" - the extensive practices of investigation and representation that go into constructing a thickly contextual social biography of capitally charged defendants, pursued with the sole aim of preventing a sentence of death. I have found in my respective roles as participant and observer that mitigation's advocates number among some of the most inquisitive, intellectually ravenous individuals I know. This is for good reason. Perpetual analytical movement functions as the defense's response to thought paralysis. This article addresses the ways in which mitigation's mechanics of knowledge production work to defy the government's processes of objectification-the defense's life-minded "movements," as it were, against analytical death.

Anthropologists in the humanistic vein will be struck by how capital defenders describe their practice. One wellknown litigator, in a practitioner's guide to "Telling the Client's Story," emphasizes the need to cull narratives from witnesses who understand the client's life experiences in humanizing terms-a crucial goal in undertaking the "painstaking investigation ... into the life and background of the client" (Bright 2017:319). Another advocate speaks of mitigation's "transformative capacity to enable jurors to feel human kinship" with an individual whom the selfsame jurors have just found guilty of murder (Stetler 2007-2008:237). In the spirit that animates the 
words of these practitioners, I see important resonances with Ghodsee's reflections on her years of ethnographic fieldwork in post-Communist East Europe: "[M]y favorite souvenirs," she writes, "have always been the personal stories that I collected along the way" (2011:14). Capital defense advocates and humanistic anthropologists alike, eager to give and receive some sense of the "felt life" of human experience (Grindal 1993:47), value stories as an essential currency of our respective trades. Yet, these narrative drops of gold do not fall into our laps simply for the asking. They must be cultivated into tenuous existence through highly fraught processes of analytical and emotional labor that begin long before we come face to face with our would-be storytellers. To scholars interested in explicit projects of humanization outside the academy, this article proposes that there is something anthropological not just about mitigation's humanizing ends but also about its deeper methodological means.

\section{Perpetual Analytical Movement: Epistemological Affinities Between Capital}

\section{Defense Advocacy and Academic Ethnography}

Capital defense advocacy, in my telling of it, starts with mitigation's practitioners themselves, in the pre-trial nitty-gritty of cultivating their own receptivity to knowledge through granular, consciousness-expanding processes that had me as a young researcher marveling before the many bookshelves of the investigation agency that served as my home base for fieldwork. It was a feast for eclectics: a full decade later, among the works that remain in my mind are Robert Edgerton's Cloak of Competence, Doris Lessing's The Golden Notebook, Orwell's Essays, all then-existing editions of the Diagnostic and Statistical Manual of Mental Disorders, science fiction by Ursula Le Guin, analyses of collective efficacy by Sampson and Raudenbush, and 9/11 terrorism reporting by New Yorker staff writer Lawrence Wright. The perpetual analytical movement, I began to realize, is fueled by a wide-ranging search for inspiration. The search's urgency became all the more apparent as my field activities expanded to its full range of sources, which included interviews with elite practitioners (attorneys, experts, and the specialized sentencing investigators referred to in the practice as "mitigation specialists"), fieldwork observations, pedagogical materials from capital defense advocacy trainings, articles published by advocates in both academic and practitioner-based forums, and redacted work product and formal court filings from then ongoing capitally charged cases.1

What began to occur to me, too, as I walked time and again past those bookshelves, was how very ethnographic-like mitigation's knowledge practices appeared to be. I refer not just to the external trappings of its "qualitative" methodology, including the cobbling together of multiply and densely theorized investigative plans that would see unending revision as empirical discoveries unfolded; the rapport-building with "informants" who could tell about the client's life; the actual interviews themselves, prized as much for their material content as for their relationship-sustaining effects with interviewees and others connected to them; 
the immersive participant observation in the defendant's various communities, however defined; the copious notetaking; the searches through archives, public and private; and, of course, the reading of seemingly infinite manners of text, with that task's accompanying sense of never being quite caught up.

These superficial similarities were fascinating, but of deeper consequence seemed to be the underlying epistemological affinity that this novice fieldworker, freshly steeped in anthropological theory, came to discern between mitigation's brand of advocacy and certain academic practices of ethnographic inquiry. In particular, I was contemplating vibrant conversations in contemporary anthropological ethnography that self-reflexively adopt a particular methodological posture toward the yet-unknown, or "unforeseen" (Strathern 2004:5). This is a sense of generous receptivity toward information, motivated by the anticipation of unexpected analytical connections to be drawn in the course of returning again and again to data, and to the always reconstituting fields that procure them.

Capital defense advocacy's antidote to thought paralysis draws its potency from a cocktail mix of strategies focused on practitioners' continuing cultivation of an eminently ethnographic attitude toward engaging the unknown. This is critical in light of mitigation's ambitions to promote the most nonjudgmentally open-minded understanding possible of a single human existence. Humanistic ethnographers may not be surprised to see some reflection of our epistemological selves in the ethos of capital defense. To recognize the "ethnographic" in mitigation's brand of advocacy, however, is also to wonder what might be deemed "advocative" about ethnography.

Here, it is important to note that according to received wisdom among mitigation's practitioners, once a case has been set on the docket for actual trial, the client is already on his way to the gallows. True "wins" for the defense usually come not by swaying jurors through the power of narrative but by negotiating with the prosecution for guilt-admitting plea dispositions that avoid both trial, with its many tribulations, and a sentence of death. In this more unbounded sphere of the practice, advocacy can and does happen through the presentation of stories that move-but it also happens through the grind of ethnographic labor itself, with analysis and action spinning off on surprising trajectories that reconstitute and push the boundaries of the original imperative to humanize. This is advocacy on an ethnographic register. In probing the epistemological affinities between academic ethnography and mitigation, then, I hope to suggest that humanistic anthropology, ever conscious of the political stakes of its trade, might find some inspiration in speculating how academic projects of humanization, too, can generate advocacy effects along the way.

\section{Anticipation as a Methodological Posture}

For those who set standards of practice in capital defense advocacy, there is a significantly anticipatory element to mitigation's data collection. In lecture notes prepared for a national training conference, one well-known 
mitigation specialist states: "Life history investigations involve interviewing the client and virtually everyone who has ever known the client, and finding every piece of paper regarding the client ever generated." In her view, advocates should cast their nets wide at the outset, with the expectation that only later can they appreciate the thematic connections to be drawn therein. Two advocates, writing for a magazine published by the nation's largest criminal defense bar association, affirm that the capital mitigation advocate cannot predict beforehand what sources of fact will prove to be most important. "That is why you need to get them all," they explain, "It's like panning for gold-you gather all available material, then meticulously sift through it for the valuable parts" (Blume and Leonard 2000:64). The expectation, of course, is that something of value is to be had-but only with patience (and much tending to detail) is analytical worth revealed.

When I asked what defense teams are looking for, one of my interviewees, a trial attorney, emphasized that, "You don't really know. The point is just to get as much as you can, go back to your sources as you need to, and put off strategy for later." Another advocate commented that a consequence of this intentional mentality of not knowing is that investigation is necessarily "cyclical, rather than linear," in the sense that facts themselves, in addition to their sources, must be constantly revisited, replenished, and reconstituted as tentative themes emerge and evolve from the data. One could say, then, that in mitigation investigations, information takes shape by working through "fields" - sets of human and informational resources to which the advocate can later return to develop theories and strategies whose trajectories were not initially evident.

I was struck early on in my research by what I perceived to be a methodological affinity between mitigation's knowledge practices and works of anthropological ethnography concerned with assessing contemporary social conditions. According to Marilyn Strathern, much analysis in cultural anthropology responds to "a kind of routine crisis in the pursuit of knowledge, which is how to deal with the unforeseen" (2004:5). Against the dynamic backdrop of increasing globalization, phenomena have come to seem interesting, anthropologically and more generally, because of a heightened sense of unpredictability that attends the exhaustion of formerly dominant paradigms, encounters across difference, unstable objects of study, and unexpected and far-flung connections (Fortun 2012; Faier and Rofel 2014; Greenhouse et al. 2002; Tsing 2005). Social analysts believe themselves trying to catch up to a world that seems ever more interdependent yet ever more unruly. In attempting to cope with the unforeseen, ethnographers of the contemporary adopt a generously expectant orientation toward information-a receptive sensibility that lends an open-ended quality to the analyst's methodological positioning.

As Strathern describes it, this "anticipation by default" involves the intentional attempt "to anticipate a future need to know something that cannot be defined in the present" (2004:7): 
[T]he would-be ethnographer gathers material whose use cannot be foreseen, facts and issues collected with little knowledge as to their connections. The result is a "field" of information to which it is possible to return, intellectually speaking, in order to ask questions about subsequent developments whose trajectory was not evident at the outset... One way of ensuring that at least there will be some resources to hand lies in an old axiom which once accompanied the rubric, namely that data has to be collected "for its own sake." (p. 9)

The immersive, heavily empirical approach of ethnographic fieldwork is motivated by the promise of establishing such analytical connections with the benefit of an ever-evolving hindsight. The more generous a view the analyst has of what might turn out to be of value, the more expansive the field of information she will create for herself, and the greater the potential that relevance will be discovered, eventually, in materials and human relationships she can return to again and again. In the face of unpredictability, then, Strathern's "anticipation by default" is not about prognosticating an increasingly elusive future. It is rather about generating possibilities that one knows will be defined largely in retrospect, after some material from the swirling currents of social life has been approached and apprehended (from the Latin prehendere, "lay hold of"). In this respect, ethnography is "a mode of enquiry which will enable a return to fields of knowledge and activity in the hindsight of unpredicted outcomes, and which will thus enable recovery of material that investigators were not aware they were collecting" (Strathern 1999:25). In the visiting and revisiting of reconstituting fields, with their repercussions for the ceaselessly unfolding nature of analysis, the process of social inquiry becomes recursive.

This methodological posture that Strathern describes is much in line with capital defense advocates' orientation of unassuming receptivity. The similarities may appear curious at first. Contemporary anthropological ethnography explores phenomena that are emergent, forward looking, and quite contingent; sentencing mitigation focuses largely on a life already lived.2 But as an object of analysis, that lived life of the defendant remains, always, on unsteady ground. In a classic introductory article on capital mitigation written for practitioners, an advocate explains one aspect of this in basic, nuts-and-bolts terms:

It is insufficient to talk to witnesses only once because each new individual recalls different facts and anecdotes; if an aunt provides an account of a head injury which the mother forgot to mention, it is necessary to go back to the mother to ask about it. Similarly, an interview may reveal records that must be obtained, which in turn raise new questions, questions which necessitate interviewing several witnesses again (Norton 1992:45).

Addressing the theme of childhood abuse that pervades the biographies of so many capital defendants, the excerpt below, from a mitigation specialist's internal teaching memorandum to investigator trainees, highlights a more nuanced point concerning the often fraught nature of mitigation investigations and the data they seek to reap: 
Witnesses to abuse and perpetrators are extremely reluctant to divulge accurate information about the nature and frequency of abuse within the household. Interviews around issues of abuse are likely to fracture and disrupt family functioning and cause non-cooperation with some family members-especially the perpetrators. Shame, embarrassment, and fear initially create barriers to accurate disclosure, and the mitigation specialist must exercise skills aimed at overcoming those barriers. She must build an atmosphere of trust and respect for the witness and provide confidentiality for disclosure. Multiple and lengthy interviews over time are necessary in order to create a protective climate that allows reluctant and fearful witnesses to provide accurate information (Holdman n.d.:14).

The first passage identifies typical challenges of field research - the incomplete quality of "found" information, the biases that produce multiple perspectives on the "same" phenomena, and the constant need for further elaboration and triangulation of the data. The second passage goes a step beyond in evoking the potentially precarious nature of thematic terrains to be explored-the tensions that test the relationships between advocates and mitigation witnesses (whose most helpful insights will almost certainly not come with a subpoena compelling them to testify) and that keep those relationships and their investigative yields ever in flux. In both instances, the objects of analysis already resist steady hold. They therefore call for a sense of humble methodological open-endedness.

But there is a third, additional pressure that imputes to mitigation's anticipation of unexpected connections a sense of imminence on par with that of contemporary anthropology. As they visit and revisit fields of information and human relations, elite defense practitioners, driven by the urgency of keeping analysis in motion, continuously strive to reconceptualize the "same" data in different terms, and in deliberately generative ways. In other words, the defendant's history, rather than being viewed as a static, already-past entity to be fully apprehended (laid hold of), instead is treated as adaptable raw material that can be analytically primed to produce further analytical movement, either in the protraction of investigation or in formal maneuvers of legal advocacy. In my experience in the practice, the palpable excitement that can come with discovering new conceptual configurations of old data very much reflects a sense that advocacy's "movements" for life have brought the defense to the cusp of something emergent, forward looking, and quite contingent. I shall demonstrate this later with an extended example from fieldwork.

For now, I suggest merely that the similarities between mitigation and ethnography are more than fortuitous. Certainly, there exist direct channels of communication between the two. Academic articles by ethnographically trained advocates have directly spelled out elements of an intuitive theoretical and methodological symbiosis between anthropology and death penalty defense advocacy (Keefe 2010; Wright 1992). One analysis from the legal academy has gone so far as to assert that: "Ethnographic practice in all aspects of a capital case is a standard to which aware and diligent defense counsel have long subscribed" (Holdman and Seeds 2008:896). 
One of my field contacts keeps informed about broad developments in the social sciences in his capacity as a training organizer for capital defense advocates across the country. A major conference he has directed featured a panel on "Anthropology, Sociology, and Historians as Defense Experts." Another advocate-the head of the mitigation investigation agency that housed all those bookshelves (and herself a formally trained cultural anthropologist!) - noted to me that good defense advocates "embrace the unwieldiness of information" when immersing themselves in processes of data collection that are "exhaustive, rigorous, and open-ended." For her, the relationship between the defense team, the information it gathers, and the sources of that information (which, crucially, include the human beings in the client's life) is a perpetually unfolding one that must be understood to be "cyclical in nature." An academic ethnographer with significant experience testifying as a defense expert in capital cases described to me what he thought to be an explicit connection between the lifeminded goals of capital defense advocacy and certain historically prominent concerns of anthropological inquiry. He noted that both knowledge practices require a "nonlinear, circular, iterative" approach to making sense of those qualities that one could take to be essential features of "the human."

But the true source of this shared posture of anticipation lies not only in the extant dialogue between capital defense advocates and academic ethnographers. More fundamentally, it reflects common concerns of knowledge production that make such dialogue possible and sought out in the first place. For life-minded advocacy, anticipatory generosity is a necessary component of its practices of cultivating conditions for surprise-but on a more concrete level, it is also a required response to thematic preoccupations that mitigation shares with contemporary ethnography. I note the anthropologist Michael Fischer's call for ethnographic attention to the "reconstruction of society in the wake of social trauma caused by world war and civil and ethnic wars; collapse of command economies; massive demographic migrations and diasporas; and postcolonial and globalizing restructurings of the world economy, including the production of toxics and new modalities of longterm risk" (2003:457-58). This reads like an investigation plan outline for a client of mine who grew up in a former Soviet bloc country. Fischer cites these themes as posing special challenges for contemporary ethnography and thus urges anthropologists to engage with "historians, literary theorists, media critics, novelists, investigative or in-depth journalists, writers of insider accounts (e.g. autobiographers, scientists writing for the public), photographers, film makers, physician-activists, and others" (p. 458). Mitigation's practitioners see the same themes and similarly seek out perspectives from diverse arrays of knowledge.

With such grand forces sweeping across space and time, the deepest engagement possible with the widest fields possible seems to hold some welcome promise of an adequate response, both for the capital sentencing advocate and for the anthropological ethnographer. Interviews are conducted, archives pored through, informant networks established. Notes accumulate and are categorized, shuffled, then reshuffled. Contacts are visited once, twice, again. All the while, the bookshelves at my ethnographic home base continue to swell. $\underline{3}$ 


\section{Ethnographic Advocacy Alongside Empiricism}

The mere fact of overlapping thematic concerns still begs the question of why such concerns must require a specifically "ethnographic" approach to mitigation's knowledge practices. What, as a practice of advocacy in furtherance of the defendant's interests, does mitigation stand to gain from being so deliberately, generatively, and ethnographically open ended? The explanation I offer calls for a clear view of what defense practitioners believe themselves up against; and this, in turn, involves further elaboration of the general epistemic conditions that have created analytical challenges for mitigation's advocates and academic ethnographers alike, consequently paving the way for their strong methodological affinities.

I offer some observations by Bruno Latour, who argues empiricism's aspirations toward "objective" inquiry have operated on the assumption of two distinct ontological domains. Phenomena in the world exist a priori; words to represent that world follow post facto. Empiricist analysts have come to understand the task of scientific inquiry to be the establishment of correspondences "directly from objects to words, from the referent to the sign" (Latour 1999:40). This sort of referentiality is taken to involve an "act of pointing or a way of keeping, on the outside, some material guarantee for the truth of a statement," such that knowledge "reflect[s] a real external world that it resembles via mimesis..." (p. 58). The object of analysis, and the analyst's investigation of it, precede her representation of it. The central project for empiricism thus becomes how to improve the quality of representational mimesis to maximize the preservation of truth. This is the problem of adequatio, or adequation, between representations and the "found" phenomena they are supposed to resemble.

In a capital prosecution, the state's quest for objectification is, in this regard, quintessentially empiricist. Prosecutors investigate and present proof of the atrocity of the crime and its catastrophic consequences. This telling, in turn, purports to stand as a fully adequate representation of the defendant's entire personhood. According to one psychological expert highly regarded in the defense community, "[P]rosecutors [in capital cases] encourage jurors to make their ultimate sentencing decision on the basis of isolated, albeit tragic and horrible, moments of aggression that they offer, in the absence of any other information, to represent the defendant's entire life and worth as a person" (Haney 1997:1456). For elite defense advocates who believe that no words or evidence can ever comprise a fully adequate representation of a human life, this process of analytical reduction is one that "death-qualified" American jurors are only too prone to embrace. $\underline{4}$ Consequently, zealous advocacy for life demands a deliberate shifting of analytical ground, even as the formal frameworks of litigation would have the defense "representing" the client-both in the sense of advocating for him, and also in the literal sense of adducing the collection of facts that would speak for his life.

How are defense practitioners to negotiate this tension? Here, I point to analogues in the research processes of contemporary anthropological ethnography. Under the methodological rubric Strathern describes, ethnography 
finds much of its purchase in the push and pull of two related activities. First, information and relations from various fields provide a foundational pool of resources that draw the analyst into its space on its own terms, independently, to a considerable extent, of her interests and prefabricated constructs. But second, the analyst routinely draws from these fields in order to produce ethnographic products-representations-that are actively and multiply theorized, typically with the further development of theory being a primary aim of immersive field engagement. This dual process of investigation and then representation is, again, the hallmark of empiricism - but the end is not adequatio. On the one hand, the fields of material are lively entities that sweep the analyst up in their ebbs and flows. She immerses herself in them and receives them generously, often with only the vaguest intuition of their possible implications. It is the analyst's anticipation of unforeseen connections that induces her to experience these fields of information and fieldwork relations on their own terms, recognizing that they have a life of their own. On the other hand, the fields of material require definition, evaluation, and, at some point, representation-but here, representation takes on a self-consciously provisional bent and is offered with specific, transparent caveats as to its purposes, the provisionality of said purposes, and the potential paths for analysis along divergent directions. Conviction lies not in acceptance of the final authority of any one representation but in the anticipatory faith that, always, there may be something more to be said. $\underline{5}$ The efforts of capital defense advocates to unsettle the state's reductionist designs proceed through practices quite parallel to those of ethnography-first, in drawing the analyst into the lively ebbs and flows of mitigation's fields of knowledge and next in constantly constructing variously theorized, provisional representations that are purposefully designed to open the door to further representations. As an example of this, I offer the following from a capital case involving a client who killed his maternal grandparents:

Details of the history of abuse survived and witnessed by [defendant] are relevant to guilt issues as well as penalty issues. It is likely that [defendant] suffers from an underlying mental disorder whose genesis can be tied to his treatment at the hands of his parents and maternal grandparents. Long-term consequences of abuse cause victims of abuse to develop a range of psychiatric disorders that distort their perceptions of reality, create altered states of consciousness such as dissociation or fugue states, cause post-traumatic stress disorder, and contribute to severe depression. Each of these reactions to abuse could shed light on [defendant's] mental state at the time of the offense and answer serious questions about facts of the offense. For instance, prosecutors argue that overkill-the use of more force than necessary to kill-is a sign of premeditation or depravity. In cases where the child kills the abuser, however, overkill is common and is seen as a measure of the child's fear of the abuser rather than the intent to inflict injury. Details of the abuse history within [defendant's] home also offer insight into the relationship [defendant] had with his codefendants.

This excerpt is taken from a defense court filing seeking to obtain funding to hire a psychological expert on child abuse. Clearly, investigation is underway. Fragile human relationships have been forged; sensitive information 
has been revealed. Of particular interest for present purposes is how the defense loops together the legalistic issue of mens rea (state of mind) at the time of the offense with the mitigating theme of repeated abuse pervading the defendant's childhood. Overkill, with its supposed implications of premeditated intent and depravity - the kinds of factors that make for aggravated and thus capital-level homicides-is recast in what the defense argues to be but one surface manifestation of a deeper, more psychologically accurate counternarrative that tells of the consequences of that abuse. The judge hears the argument, grants the funding, and, in a very real sense, becomes a stakeholder in the development of that counternarrative, with its concomitant need for full investigation into the intensely guarded family life of the client and the heretofore unknown psychiatric impairments associated with the client's individualized experiences of traumatic abuse. From this shared starting point nested within the doctrinal frame of criminal intent, the defense has already started to prime the judge to allow would-be jurors (for they are not yet empaneled) to hear increasingly expansive, humanizing evidence advancing the case for life. All this occurs well before the accused's guilt has been litigated and established beyond any reasonable doubt.

In this example, advocacy proceeds by fostering in the judge a deliberate and generative sense of openendedness toward analytical connections that remain to be discerned. To put it another way, advocacy is operationalized through a powerful third party's adoption of the same sense of anticipation by default that mitigation's practitioners work so hard to nurture among themselves. Prosecutors present the defendant's act of overkill as one of horrific violence-a manifestation of inexcusable cruelty and evil. In response, mitigation's practitioners surrender to the "field" of the client's tumultuous family life on its own delicate terms, cultivating conditions that permit the revelation of elusive, highly charged truths. All the while, advocates scan their knowledge horizons for conceptual perspectives (here, psychiatric frameworks of traumatic abuse) that allow for the "re-presentation" of those facts about overkill in ways that call for further investigation and additional representations. This process exhibits the external trappings of empiricism-its hallmark features of investigation preceding representation, its designs on obtaining "the fullest information possible." However, there is an impetus that lies orthogonal to it. This other project uses a conceptual space of agreement (here, the need for expertise within the parameters of a specific issue of litigation) as a springboard from which to movejointly, ethnographically - to new, different, and more open-ended representations that can illuminate everdiverging and ever-diversifying aspects of the client's personhood. Advocacy, though heavily empirical, is thus something besides strictly empiricist.

In sum, this case filing demonstrates how the stimulation of analytical movement, as a vital response to the state's processes of analytical objectification, produces tangible advocacy effects that bolster the defense's case for life. But the real work of advocacy does not begin or necessarily culminate in the formal strictures of court processes. Neither does it always proceed through instances of successfully "humanizing" the defendant 
through the direct transmission of stories, be they narrative or counternarrative. In the chase for those stories, advocacy can occur through the keen discernment of analytical paths that appear unexpectedly along the way, taking the work of humanization in different directions. Back, then, into the swirling currents of social life, where I now present some ethnographic material of my own on the visiting and revisiting of a single curious document, and the construction and reconstruction of that document's various fields.

\section{Anticipation in Action: An Ethnographic Example $\underline{6}$}

\section{Moment 1}

A fragile human relationship has been forged. Sensitive information teeters on the cusp of revelation. María, our client's biological aunt and sole childhood caretaker, has just granted the defense team her signature on a blanket release of any and all institutional records in the country attached to her name-immigration, hospital, welfare, social services, tax, employment, vital, everything. Obtaining such releases from the defendant and as many of his intimate others as possible is standard practice in capital mitigation. Still, the task causes great anxiety for even the most seasoned advocates. The lifelong conditions that have enabled a human being to commit death-eligible homicide are occluded by what people around him would prefer to keep hidden-and now, the field of the aunt's personhood is about to arrive in our office mailboxes in batches of digital files encoded on disc. Today, we know, signals a major step forward in the cultivation of our relationship with the client's family and in the development of his substantive case for life.

But María is presently pondering a somewhat different field. Do we also need records from her country of origin, she wonders? We have in fact already begun to query how to obtain them through various channels abroad (though the bureaucracy there, as we expected, has proven slow, rife with corruption, and frustratingly unreliable). She presents us with a few files she has on hand, all in Spanish. One stands out: María has a criminal record for drug possession in her homeland. As it so happens, our client's capital charges are bound up with his alleged activities as a narcotraficante (narcotics trafficker). I scan my knowledge horizons, linger on Sutherland's differential association theoryz_-and we, the defense team, collectively ready ourselves in anticipation of the story to be told. How does it begin? María demurs when pressed, gently, to share. It will have to wait, maybe another day, maybe forever. But this day has already revealed itself one for which to be grateful.

\section{Moment 2}

The aunt's criminal record is causing us great despair. The prosecuting state, now aware of María's drug offense, has indefinitely prohibited her entry into the jail where our client awaits trial. The illegal drug trade is an international one; no need to facilitate the family business. We worry deeply. The defendant's aunt, his de facto mother, has been an invaluable stalwart of emotional support for him as well as a powerful vouching influence 
for us. Her embrace of the defense team has started to translate into the sort of client trust that no advocate can ever take for granted. Our immediate reaction takes shape in the development of a directly argumentative challenge. What connection can be conclusively established between the aunt's offense and our client's putative dealings as a trafficker? What can a single isolated instance of mere possession-one that occurred decades ago, followed up by a spotless record of law abiding in both countries-have anything to do with the modern, highly sophisticated enterprise the government is presently alleging? Also, just what does that foreign conviction truly mean, anyway, not just in the context of our criminal justice system but in its own? We scour the detention facility's internal policies, American case law on inmate security, and legal doctrine abroad on small-scale drug possession. Our feet are mired in the state's sticky conceptual turf, but we are looking for a way out.

\section{Moment 3}

Then we begin to scan farther along our knowledge horizons. Our client's case is a capital prosecution. The state has declared this of its own accord. Where the government introduces the specter of death, the defense necessarily stakes out the central place of sentencing mitigation, with its endlessly evolving, cross-cutting, selfreinforcing, self-contradicting, never wholly tamable fields of social life. Based on systems theory from the practice of social work, defense advocates well know that the client's personhood is nested in imbricated systems of human relationships and that fostering live connections between him and family members "serve[s] the social work principle of strengthening and restoring the individual's and the family's well-being, while simultaneously satisfying the legal principle of gathering the strongest evidence possible for the sentencing phase" (Hughes 2009:375-76). We have already witnessed this with the aunt's vouching. The defense asserts that severing our client's connection with the single most influential personality from his formative years constitutes the government's active interference with the carefully developed, densely interwoven mitigation investigation that is constitutionally mandated of us. Their denial of the aunt's access to her de facto son, we argue, will haunt the prosecution as a litigable issue on post-conviction review, should our client be sentenced to death.

The state grants María access, one time only, for the purposes of capital sentencing mitigation. On some level, this is a victory for the defense. It does not feel like one to any of us. For an instant, we consider whether to stage direct what will be the last mitigation-generating interaction between mother and child, but the thought quickly gives in to better intuitions. This time is theirs. We seat ourselves to the side of the jail's attorney-client conference room, avert our eyes, wanting and not wanting to listen and, just as they do, cry.

\section{Moment 4}

María expresses yet again how much she appreciates what we did. Today, she begins to talk about her husband. He was a narcotraficante. That drug possession offense from years ago was a collateral consequence of her 
relationship with him. He died young. Our client, a young boy without parents, looked up to the man as a hero. Yes, the drug trade appears to be the family business. But another narrative is waiting to be told.

\section{Moment 5}

The aunt's records from abroad will surely contain something relevant to this story. If only we can get them. We contemplate once more the significance of María's drug offense in the context of its own jurisdiction: in a land where the construction of local meanings is inextricably entangled with the corruption, graft, and incompetence that sully the credibility of recorded truths; and in a regime where recorded truths pool heavy in dusty, nondigital archives, far away from our office mailboxes. What does that criminal record mean? It seems impossible to suss out the implications.

Then something appears along our knowledge horizons. It becomes more and more apparent that María's court document-an artifact we have been framing in the problematic issue of our client's imprisonment and then in the more auspicious project of sentencing mitigation-is also part and parcel of a swirling field of material generated in a foreign prosecutorial system sullied by corruption, graft, and incompetence. We are realizing a newfound importance in this. Our own government's case against the defendant relies substantially and materially on volumes of witness testimony and on investigative leads procured in that very same corrupt foreign system. In other words, factors that originally presented themselves as a peripheral (and parenthetically mundane) nuisance in the mitigation-related pursuit of the aunt's records are now asserting themselves front and center as a means of contesting the reliability of proof about our client's criminal culpability. Forget the question of capital sentencing; is the defendant even guilty of what the government says he is? We file the argument, and the state responds with an offer that comprises a classic "win" for capital defenders: a trialavoiding plea bargain for a life sentence without the possibility of parole.

This narrative does not have to end here. Our client could opt to reject the plea. We would then have no choice but to continue perpetuating our advocacy efforts, these nonstop, always roving movements for life-one of which would include the ongoing hunt for María's records abroad. But in this case, we have already been vouched for. The defense team strongly encourages our client to accept the deal. Trusting our judgment, and his aunt's, he does.

\section{Conclusion: Ethnographic Advocacy for Life}

These advocates could have retained a strict focus on delivering the most compelling mitigation narrative possible at a sentencing trial. But by raising the specter of doubt about the client's guilt, the defenders keyed in on an issue they knew would resonate with potential jurors (and thereby prosecutors) in portraying the death penalty as a cruel and unusual punishment in this case. It was ethnography's granular, generously anticipatory 
processes that laid the groundwork for the pivot between a narrative-centered project of humanistic advocacy on the one hand and a more technical, jurisprudentially oriented, but no less humanistic one on the other. I submit that the endeavors described above constituted a powerful practice of advocacy. Yet, the advocative essence of these efforts lay not in ironclad rational argument, nor in charismatic courtroom personalities, nor in forceful assaults of persuasion. Nor, despite journalistic observations that suggest mitigation's tendency toward the maudlin (Kotlowitz 2003; Richards 2006), did they rely solely on the presentation of empathy-evoking stories. Advocacy developed instead through organically derived effects of keeping knowledge on the move, in the continued stoking of curious, lively, and life-minded inquiries into analytical possibilities that just might surprise, if only one would let them.

My discoveries from the field thus resonate with Kim Fortun's contemplation of a kind of advocacy that is not ... limited to those instances in which people assert what they believe to be true in the expectation that others will concede. Desire for rational consensus is not always the goal here. Advocacy without the guarantees of teleology is of particular interest. Intentionality is examined, but not assumed. The challenge here is to uncouple advocacy and modernist ideals (2001:16).

Such modernist ideals hold themselves out to promote the ends of progress, achieved with the exercise of an analytical prowess aimed at the "final synthesis" of any given event, entity, or phenomenon (p. 350). But adequatio's aspirations toward epistemological mastery comport too well with the sort of analytical reduction that would allow the prosecuting state to achieve the clean, surgical excision of defendant from society. Consequently, mitigation's elite advocates refuse to be modern (Latour $\underline{1999}$ ), even as they outwardly perform activities that appear to play by adequation's modernist rulebook.

As humanistic anthropologists mine the ethnographic terrain for stories that convey the "felt life" of human experience, we may view our knowledge endeavors to be significantly aligned with mitigation's comportment toward open-ended understanding. But, just as with capital defense practitioners, if scholars pursue the polished presentation of those stories (or the academic monograph) as the be-all and end-all of our ethnographic labor, then we may very well miss unforeseen chances for advocacy along the way. We may ask, then, what pivots we anthropologists might help to open up through "forms of elicitation, demonstration, and accessibility to publics and readerships in process" (Marcus 2013:203), in the course of ethnographic doings that enable not only the procurement of humanizing stories but also the realization of other political commitments for which we may be distinctly positioned to advocate.

This is a large question, the responses to which will surely vary, probably quite widely, depending on the case. But I am immediately reminded of the legal philosopher Martha Nussbaum's insistence on knowledge projects that are "open-ended and revisable because grounded upon dialectical arguments that have their roots in 
experience" (1994:718). Nussbaum speaks of the aspiration toward general human flourishing. Hence, it is particularly suggestive that at the heart of her vision -the perpetuation of experience-based life in analysis-the methodological signature of academic ethnography can be clearly discerned. In capital mitigation, this cultivation of analytical life has direct implications in sustaining a literal human breath. What humanistic projects of epistemological possibility can anthropologists keep alive-or breathe life into, or even give birth to-through our own field engagements? What manners of ethnographic advocacy can academic anthropology surprise itself with, uniquely informed as our practices are by the textures of theory, empirical richness, and meticulous human relationship building? The nature of these knowledge projects, I believe, will ultimately lie in the specific processes that inhere in the analyst's reflexively intentional attunement toward opportunities for open-ended knowing, and the crafty capitalization of those opportunities when they arise.

\section{References}

- Blume, John H., Stephen P. Garvey, and Sheri Lynn Johnson 2001 “ Future Dangerousness in Capital Cases: Always 'At Issue'." Cornell Law Review 86( 2): 397- 409.

- Blume, John H., and Pamela Blume Leonard 2000 " Capital Cases: Principles of Developing and Presenting Mental Health Evidence in Criminal Cases." The Champion 24: 63-71.

- Bowers, William J., Marla Sandys, and Benamin D. Steiner 1998 " Foreclosed Impartiality in Capital Sentencing: Jurors' Predispositions, Guilt Trial Experience, and Premature Decision Making." Cornell Law Review 83( 6): 1476- 556.

- Bright, Stephen B. 2017 "Telling the Client's Story: Developing a Consistent Theme for Life Imprisonment without Possibility of Parole." In Tell the Client's Story: Mitigation in Criminal and Death Penalty Cases, edited by Edward Monahan and James Clark, pp. 317-40. Chicago, IL: American Bar Association.

- Butler, Brooke, and Gary Moran 2007 "The Impact of Death Qualification, Belief in a Just World, Legal Authoritarianism, and Locus of Control on Venirepersons' Evaluations of Aggravating and Mitigating Circumstances in Capital Trials." Behavioral Sciences and the Law 25: 57- 68.

- Cowan, Claudia L., William C. Thompson, and Phoebe C. Ellsworth 1984 “ The Effects of Death Qualification on Jurors' Predisposition to Convict and on the Quality of Deliberation." Law and Human Behavior 8: 53- 79 .

- Faier, Lieba, and Lisa Rofel 2014 " Ethnographies of Encounter." Annual Review of Anthropology 43: 363- 77. 
- Fischer, Michael M. J. 2003 Emergent Forms of Life and the Anthropological Voice. Durham, NC: Duke University Press.

- Fortun, Kim 2001 Advocacy after Bhopal: Environmentalism, Disaster, New Global Origins. Chicago, IL: University of Chicago Press.

- Fortun, Kim 2012 “ Ethnography in Late Industrialism.” Cultural Anthropology 27( 3): 446- 64.

- Ghodsee, Kristen 2011 Lost in Transition: Ethnographies of Everyday Life after Communism. Durham, NC: Duke University Press.

- Carol J. Greenhouse, Elizabeth Mertz, and Kay B. Warren, eds. 2002 Ethnography in Unstable Places: Everyday Lives in Contexts of Dramatic Political Change. Durham, NC: Duke University Press.

- Grindal, Bruce T. 1993 " The Spirit of Humanistic Anthropology." Anthropology and Humanism 18( 2): 46- 7.

- Haney, Craig 1997 “ Violence and the Capital Jury: Mechanisms of Moral Disengagement and the Impulse to Condemn to Death." Stanford Law Review 49: 1449- 86.

- Holdman, Scharlette n.d. "Continuation Necessary for Mitigation Specialist and Role of Mitigation Specialist." Unpublished legal memorandum on file with author.

- Holdman, Scharlette, and Christopher Seeds 2008 " Cultural Competency in Capital Mitigation." Hofstra Law Review 36( 3): 883-922.

- Hughes, Emily 2009 “ Mitigating Death.” Cornell Journal of Law and Public Policy 18(2): 337- 90.

- Keefe, Susan 2010 “ The Anthropologist as Expert Witness in Death Penalty Mitigation." Practicing Anthropology 32( 4): 4-8.

- Kotlowitz, Alex 2003 "In the Face of Death." New York Times Magazine, July 6. Accessed on March 5, 2018. http://www.nytimes.com/2003/07/06/magazine/in-the-face-of-death.html?pagewanted=all.

- Latour, Bruno 1999 Pandora's Hope: Essays on the Reality of Science Studies. Cambridge, MA: Harvard University Press.

- Lofland, John, and Lyn H. Lofland 1995 Analyzing Social Settings. 3rd ed. Belmont, CA: Wadsworth.

- Marcus, George 2013 “ Experimental Forms for the Expression of Norms in the Ethnography of the Contemporary." Hau: A Journal of Ethnographic Theory 3( 2): 197- 217. 
- Maurer, Bill 2005 Mutual Life, Limited: Islamic Banking, Alternative Currencies, Lateral Reason. Princeton, NJ: Princeton University Press.

- Norton, Lee 1992 “ Capital Cases: Mitigation Investigations.” The Champion, May.

- Nussbaum, Martha 1994 " Skepticism about Practical Reason in Literature and the Law." Harvard Law Review 107( 3): 714- 44.

- Richards, Sarah Elizabeth 2006 "How to Humanize a Killer." Salon, June 7. Accessed on March 5, 2018. http://www.salon.com/2006/06/07/mitigation specialists/.

- $\quad$ Skipper v. South Carolina, 476 U.S. 1 (1986).

- Stetler, Russell 2007-2008 “ The Mystery of Mitigation: What Jurors Need to Make a Reasoned Moral Response in Capital Sentencing." University of Pennsylvania Journal of Law and Social Change 11: 237-60.

- Strathern, Marilyn 1999 Property, Substance and Effect: Anthropological Essays on Persons and Things. London: Athlone Press.

- Strathern, Marilyn 2004 Commons and Borderlands: Working Papers on Interdisciplinarity, Accountability and the Flow of Knowledge. Oxon: Sean Kingston Publishing.

- Tsing, Anna L. 2005 Friction: An Ethnography of Global Connection. Princeton, NJ: Princeton University Press.

- Wright, Isabel 1992 "Anthropology and Capital Case Litigation." In Double Vision: Anthropologists at Law, edited by Randy F. Kandel, pp. 29-42. Oxford: Blackwell Publishing. 